\title{
Pavlo KORINENKO
}

Doctor of Historical Sciences (Dr. Hab. in History), Professor at the Department of History of Ukraine, Archaeology and Special Branches of Historical Sciences, V.Hnatiuk Ternopil National Pedagogical University

(Ternopil, Ukraine), korinenko@tnpu.edu.ua

ORCID: https://orcid.org/0000-0002-4068-149

\section{Serhii PADALKA}

Doctor of Historical Sciences (Dr. Hab. in History), Professor, Leading Research Fellow,

Department of Modern History and Policy, Institute of History of Ukraine NAS of Ukraine

(Kyiv, Ukraine), seriogap@ukr.net

ORCID: https://orcid.org/0000-0001-8478-5332

\section{Natalia VARODI}

Candidate of Historical Sciences (Ph. D. in History), Docent at the Department of History and Social Disciplines,

Ferenc Rákóczi II Transcarpathian Hungarian College of Higher Education

(Berehove, Ukraine), varadinatalia29@gmail.com

ORCID: https://orcid.org/0000-0003-4175-4928

\section{Land Relations in the Context of Social and Economic Transformations of the Ukrainian Countryside During the Years of Independence: Scientific Assessments and Forecasts}

\begin{abstract}
The purpose of the study is to analyze the transformations of land relations in the Ukrainian countryside with gaining independence. Changes in land use, land management, as well as the emergence of new organizational and economic forms of management in the agrarian sector were radical, and therefore ambiguous in their nature. General scientific methods were used in the study, in particular comparativehistorical and systemic-structural, which helped to organize a significant number of source material, reproduce and compare the direction of land relations transformation at different stages of this process. The problem-chronological approach was used to determine the structure of the study. The scientific novelty consists in researching the problem, which has not been investigated in Ukrainian historiography in such a formulation and chronological framework. Agrarian reform in Ukraine, first of all, the reform of land relations, has been consistently considered from lease spreading, land subdividing among the peasants to the opening of the agricultural lands market. Objective and subjective factors, which complicated these processes and, in particular, lagging behind in the formation of a complex of legal bases were analyzed. Conclusions. The influence of land relations transformation on achievements and losses in the Ukraine's agrarian sector were highlighted. The authors state that the hasty introducing new agrarian forms of land management without proper theoretical justification, financial support has made the reform process poorly predictable for 30 years. For a long time, peasants were unsure of the irreversibility of land relations transformation, which is confirmed by the rather slow rate of State certificates of land shares ownership. It has been mentioned that the authorities were aware of the problem complexity, so a slow transition from collective and state farm system - through CAEs (collective agricultural enterprises) - to PPFs (personal peasant farms) and PSF (personal subsidiary farms) was proposed. Agro-firms and agro-holdings were the culmination of a new structure of land management. The changes in the structure of crops and livestock farming, which became the result of land relations transformation, were analyzed. Changes in the lives of peasants were traced, first of all, the attitude of most of them to small-scale production. A step-by-step review of the condition of the agrarian sector material and technical basis was made.
\end{abstract}

Keywords: transformation of land relations, land share, lease of land, farming, agricultural (farm) land market. 
With the proclamation of Ukraine's independence, the government authorities became moderators of the public requirements for the necessity to transform land relations, which were to restore agricultural producers' ownership of land and means of production, and ensure the further development of the agrarian sector on this basis. Under the transformation of land relations, a complex of organizational, legal, and economic measures of the government should be understood, which are aimed at achieving a specific goal that envisages changing the system of legal relations of land management, increasing the efficiency of the agrarian sector ${ }^{1}$. The analysis of reconstructing the traditions of land relations in the Ukrainian countryside consists in the fact that by their essence and orientation they have to influence significantly the formation of sustainable and effective institutions of land ownership, utilization, and management.

Organizational and functional assessments of agricultural production in the country have been and remain a priority direction of scientific and historical research. The historiographical analysis in this study is selective, as we pay attention to papers, which are directly or indirectly related to the problem of land ownership and land use, and, above all, changes in this area, rather than the entire agrarian sector of the economy. With the declaration of independence, the scientists of the National Agrarian University (now National University of Life and Environmental Sciences of Ukraine) began work on the problem of developing new economic forms in the agro-industrial complex. In the collective work (published in 1998), agrarian scientists presented their vision of the probable implementation of agrarian reform in Ukraine, paying attention to objective and subjective factors, which slowed down the process of reforming the agrarian sector of the economy. At the same time, the book clearly traces the main tendencies, which, in the authors' opinion, had to be further developed, in particular, the place and role of establishing private ownership of land and the searching for new approaches to solving the problem of increasing the efficiency of agriculture by new economic entities.

In 2001, the editorial board of the "Український селянин” ("Ukrainian Peasant”, published at B.Khmelnytskyi National University of Cherkasy) launched a column "Agrarian aspects of economic and political transformations of the 19 - early 21 centuries". Along with the emphasis on political and economic transformations in the agrarian sector of Ukraine, their authors pay attention to changes in land relations (S.Kulchytskyi, V.Marochko, P.Panchenko, O.Reient), and others. In particular, S.Kulchytskyi in his article "Market reforms in Ukraine" noted that as to the rate and depth of reforming production relations at the present stage, agriculture is significantly inferior to industrial sectors, although the Ukrainian political elite understood the necessity of accelerating the agrarian sector reformation in the early 1990s. Consistently analyzing the main steps of power bodies in this direction, the author paid attention to the importance of the Resolution of the Supreme Soviet of Ukrainian SSR "On forms of land ownership", of December 1990, which assumed the existence of collective and private property of land together with the state property ${ }^{3}$. The most important part of production relations transformation in the agrarian sector is land reform, during which, in the author's opinion, the slogan "Land to the peasants" had to be restored.

At present, Ukrainian scholars are radically changing their views under the influence of achievements and losses in the transformation processes, especially with regard to land ownership. The authors of this study S.Padalka and P.Korinenko in their published monographs ${ }^{4}$

\footnotetext{
Transformations, as we read in the Dictionary of foreign words, is a change, transformation of one economic system into another, accompanied by the disappearing of some elements, features, properties or the emerging of new ones. The evolutionary development of the social-economic system was the dynamic basis of the transformation taking place under the influence of various factors. Sее: Словник іншомовних слів та термінологічних словосполучень / Уклад.: Л.О.Пустовіт, І.О.Скопенко, Г.М.Сита. - К., 2000. - С.903.

Соціально-економічні аспекти реформ в агропромисловому комплексі України (1991-1998 рр.) / За ред. Л.Беренштейна, Т.Митріна, С.Кульчицького, П.Панченка, С.Падалки. - К., 1998. - 200 с.

Кулъчицький С.В. Ринкові відносини в сільському господарстві // Український селянин. - Вип.4. - Черкаси, 2002. - С.15, 17.

See: Падалка С.С. Приватизація в Україні: перші підсумки та уроки (1991-2009). - К., 2010. - 296 с.; Коріненко П.С. Трансформації земельних відносин в українському селі (IX - початок XXI ст.): Порівняльний аналіз. - Тернопіль, 2019. - 511 с.; Його ж. Правові засади аграрної політики в Україні (др. пол. XX - початку XXI ст.): Історичний аспект. - Тернопіль, 2018. - 367 с.
} 
offer an expert view as specialists on this issue on modern transformations of land relations and their scientific assessments as well as supposed prospects.

Many research problems on agrarian issues have been scientifically tested at scientific symposia on agrarian history at B.Khmelnytskyi National University of Cherkasy, which contributes to the coordination and consolidation of the efforts of agrarian historians. In particular, in 2014 at the $\mathrm{X}^{\text {th }}$ Symposium, the attention of agrarian historians was paid to the necessity of intensifying the activation of the agrarian market study from the perspective of land ownership, improving agriculture both throughout Ukraine and at the regional level; focus on studying the results of practitioners' activities in the modern agrarian sector. Also in 2000 in Cherkasy National University, the Scientific Society of Agrarian Historians was created, which immediately became the leader in developing many framework problems in the history of the Ukrainian countryside 5 .

The agrarian sector of the national economy is a direct area for scientific studies of agrarian economists, in particular such authoritative scientists as V.Horbulin, P.Haidutskyi, P.Sabluk, A.Tretiak, and others ${ }^{6}$. They investigate the economic activity of the agrarian sector entities and especially the transformation processes, offer valuable recommendations to the authorities on the optimization of land relations at the present stage and in the future. In particular, a team of economists headed by V.Horbulin, who were directly involved in the formation of agrarian policy during the years of independence, prepared a thorough analytical study on the transformation of land relations ${ }^{7}$. Scholars V.Dudko, H.Zaremba and V.Cherevko distinguish at least four major transformation processes in the history of land relations: feudal, capitalist, socialist and the present - market $^{8}$. However, they do not pay enough attention to the current stage of land relations. In the other paper, V.Cherevko remarked, analyzing the agrarian policy of agro-holdings that these new economic entities had great prospects for the agrarian sector of the economy in increasing the production of marketable products?.

It seems that the number of scientific papers of economic scholars is ahead of historians. Taking into consideration the scale of transformation in land relations and the society's expectations of concrete results, it is probably justified. For historiographical analysis, all these processes take place quite closely, which complicates their thorough analysis. At the same time, it should be mentioned that some scientific investigations of economists are characterized by excessive abundance of statistical materials, which are not always subject to indepth analysis by them.

Scholars of law are quite fruitfully analyzing the current state of land relations in the Ukrainian countryside. They substantiate the scientific and legal basis of changes in land

\footnotetext{
Seе: Панченко П. Тенденції трансформацій сільського господарства України та управління 50-80-х рр. XX ст. // Український селянин. - Вип.2. - Черкаси, 2001. - С.118-124; Мойсієнко B.M. Аграрна реформа в Україні: досягнення і прорахунки // Там само. Вип.4. - С.19-21; Тодоров I.Я. Агропромисловий комплекс України: відповідь на європейське покликання // Там само. - Вип.7. Черкаси, 2003. - С.166-170; Грищенко 3.І. Деякі аспекти аграрної політики в Україні 90-х рр. XX ст. // Там само. - Вип.10. - Черкаси, 2005. - С.369-372 та ін.

6 Гайдущъкий П.А. Аграрна реформа Л.Д.Кучми в Украӥні: історико-економічні аспекти // Економіка АПК. - 2015. - №1. С.5-13; Його ж. Аграрна реформа міфи й істина // Урядовий кур’ер. - 2003. - №172. - С.178; Третяк А.М. Історія земельних відносин і землеустрою в Україні. - К., 2002. - 280 с.; Його ж. Земельний кодекс ХХІ ст. - К., 1999. - 115 с.; Хвесик М.А., Голян В.А., Крисак A.I. Інституціональні трансформації та фінансово-економічне регулювання землекористування в Україні. - К., 2008. - 522 с.; Дорош Й. Інституціональне забезпечення розвитку земельних відносин і системи землеволодіння // Аграрна економіка. - 2011. - Т.4. №1-4. - С.79-88; Андрійчук В.Г. Агропромислові формування нового типу у контексті стратегії розвитку вітчизняного сільського господарства // Економіка АПК. - 2013. - №1. - С.3-15; Малік М.Й., Заящъ В.М. Теоретичні засади та напрями трансформації особистих селянських господарств // Там само. - №5. - С.83-95; Шарий Г.I. Сучасні земельні відносини на селі // Там само. - 2014. №4. - С.12-17; Лупенко Ю.О., Саблук П.Г., Месель-Веселяк В.Я., Федоров М.М. Результати і проблеми реформування сільського господарства України // Там само. - №7. - С.26-38 та ін.

Земельні відносини в Україні: Збірник інформаційно-аналітичних матеріалів (1991-2010рр.) / За ред. акад. В.П.Горбуліна. - К., 2010. $-196 \mathrm{c}$.

8 Дудка I., Заремба В., Черевко Г. Виникнення і еволюція аграрних відносин в Україні // Аграрна економіка. - 2011. - Т.4. - №1-4. C.138-147.

9 Черевко Г. Агрохолдинги як оптимальні форми крупнотоварного господарювання в агробізнесі України // Там само. - 2012. - Т.5. №1-2. - C.36-42.
} 
utilization and land management, pay attention to the development and interpretation of definitions on agricultural issues at the modern scientific level, as well as clarify the legal aspects of emerging and forming new structures of economic activity in the agrarian sector of Ukraine ${ }^{10}$.

As a whole, the analysis of the scientific literature shows that the interest of Ukrainian historians, economists, lawyers in the problem of land policy at the present stage is one of the priorities of scientific studies. Scientific papers are becoming more and more complex, their topics are diversified. Modern historiography of land relations in the days of Ukraine's independence offers new positive assessments of the role and place of private land ownership in the agrarian sector. However, researchers of agrarian relations are quite cautious in assessing large-scale transformations in the agrarian sector of the economy. The problem of land relations transformation in the Ukrainian countryside, studied by us, is still remaining among the priority projects. This topic is quite broad, and it can and should be investigated by individual stages and even regions. At the same time, there is an objective complexity, consisting in the fact that the transformation of land relations has not yet been completed. The course to opening the market of agricultural land will be implemented only at present. This means that the conclusions and recommendations of scientists can only be intermediate.

The transformation of land relations in the Ukrainian countryside began during the perestroika time. At the end of 1990, the Supreme Soviet of the Ukrainian SSR adopted the resolution "On Land Reform" and at the same time, the Land Code of Ukraine. The Resolution was presented as an integral part of the transition of agricultural production to market relations, during which the redistribution of lands was to be carried out with the simultaneous transfer them to peasants in private and collective ownership, as well as for using by enterprises and organizations. In the same document, it was emphasized that from March 15, 1991, all agricultural lands of the Ukrainian SSR were to become the object of land reform $^{11}$. From the very beginning of the agrarian sector reformation, the task was to help the producer become the owner of the land, ensure the independence of the peasant, the revival of landowner on the basis of private property, develop personal subsidiary and peasant farms. In fact, this was to be a radical transformation of land relations, which was carried out in two directions: general privatization and liquidation of agrarian production structures of the Soviet type. The Resolution "On Land Reform" envisaged the transformation of collective and state farms into more flexible production structures, which would be capable to make changes in the agrarian sector. Taking a more categorical position, V.Horbulin accuses the then authorities stating that "from the very beginning of the agrarian reform the State tried to bring collective and state farms to bankruptcy, and form peasant farms on their ruins. The State expropriated land from collective farms without any compensation, which negatively affected the volumes of commodity production. Land subdivision initiated changes in the system of its ownership and use at the legislative level. Clearly, it did not lead to drastic changes in the economic model. The difference was that till that time, there had been one owner - the State, and after that there appeared a large number of owners. In addition, most of them did not utilize the land. It so happened that the lands of agricultural producers did not belong to them (they were leased)"12.

The Land Code of Ukraine was to regulate land relations in the countryside both under the new conditions, which were already becoming a reality, and in the future. The core element of the Code became the fixed right of every Ukrainian citizen to land plot, which

\footnotetext{
10 Гончарук Н.Б. Правові засади утвердження приватної власності в аграрному секторі економіки України // Український селянин. 2001. - №3. - С.336-342; Фермерське господарство: правові засади створення, функціонування та припинення / М.В.Шульга, В.П.Жушман, П.Ф.Кулинич, В.Ю.Уркевич. - Х., 2004. - 464 с.; Майовець Є.Й. Теорія аграрних відносин. - К., 2005. - 276 с.; Лопатинський Ю.М. Трансформація аграрного сектора: інституціональні засади. - Чернівці, 2006. - 344 с.; Мірошниченко А.М. Земельне право України. - К., 2009. - 712 с.; Мірошниченко А.М., Марусенко P.I. Науково-практичний коментар Земельного кодексу України. - К., 2013. - 544 с.; Корнєєв Ю.В. Земельне право. - К., 2011. - 248 с. та ін.

11 Аграрна реформа в Україні. - К., 1996. - С.17.

12 Земельні відносини в Україні: Збірник інформаційно-аналітичних матеріалів (1991-2010рр.). - С.11.
} 
could be given to him in lifelong inherited possession, and to agricultural enterprises, public organizations, institutions - in permanent possession ${ }^{13}$. It is noted in the Code that no one has the right to confiscate property without landowner's consent. Land for personal peasant farms (up to $2 \mathrm{ha}$ ) and dachas (summer houses) (up to 0,06 ha) were transferred to ownership free of charge.

The methodological basis of the agrarian policy consisted in the same principles on which the collective and state farm system had once been created, namely paternalism, egalitarianism and leveling. In a broad sense, the above-mentioned methodological principles were the basis of "social engineering", which tended to experiment with the society and its separate social groups. As a rule, "social engineers" imposed those behavior patterns that determined their idea of a "bright future" and the "irreversibility of the reform processes". The process of "introducing reforms" in rural areas in the 1990 s envisaged the creation of special commissions for introducing share property relations, as well as collective farms' reformation. They explained the essence of the reform to the peasants in detail, agreed on the questions of who was to be entitled to a property share, searched in the archives for information about the year of the peasant's joining the collective farm, his payment in-kind and monetary payment of work for years on the farm, and so on. No wonder that such an approach was doomed to failure, about which sober-minded Ukrainian scholars warned.

With the proclamation of Ukraine's independence, more and more attention in land relations began to be paid to the formation of the legal framework for new economic entities. The Laws of Ukraine "On Economic Partnerships" (September 1991), "On Collective Agricultural Enterprise” (hereinafter - CAE) (February 1992), "On Peasant Farm” (March 1992) were prepared. During 1992-1995, the Government introduced three other important documents to implement the main provisions of the Resolution "On Land Reform" and the Land Code, including Government Decrees "On privatization of land plots", "On the peculiarities of property privatization in agro-industrial complex" and "On accelerating property privatization in agro-industrial complex". In accordance with these documents, property inventory making and redistributing land, allocating stock lands, establishing the boundaries of village councils territory in land use were initiated; the registration of CAEs also begun. At the same time, samples of documents were prepared, in particular, "On the form of the contract for the right of temporary use of land", the form of the Certificate for the right to land share was approved as well as the samples of the Book of land shares certificates registration ${ }^{14}$. From the viewpoint of a certain sequence of preparing the regulatory-legal framework, it seems that almost everything was reasoned out and there had to be no serious complications in the transformation of land relations and introduction of new organizational and economic forms on land. The objective complicating fact was that land relations transformation began in the conditions of state ownership of land and state-owned organizational forms (collective and state farms), which were almost the only ones in manufacturing marketable agricultural products.

In the autumn of 1991, the Government proposed to transform collective farms into associations, giving each collective farmer the right to leave the collective farm and start his (her) own farm. The Verkhovna Rada obliged local councils to withdraw 7-10\% of lands from collective farm lands and transfer them to the land reserve to be provided to farmers (yesterday's collective farmers) for arranging their own farms. To perform these tasks, in 1992, the land fund of 4 million ha was created. The following year, it rented out land plots to 18000 farmers with an area of 360000 ha (on the average, 20 ha per farm) ${ }^{15}$.

At that time, the lease relations became so widespread that the law-makers faced the task of providing this socially significant process the corresponding regulatory and legal support.

\footnotetext{
13 Коріненко П.С. Правові засади аграрної політики в Україні (друга половина XX - початку XXI ст.). - С.137.

14 Там само. - С.145.

15 Третяк A.M. Історія земельних відносин і землеустрою в Україні. - С.174-177.
} 
In 1991, the Verkhovna Rada passed the Law "On Peasant (Farming) Economy”, which laid down the development of a raft of legislation aimed at working out the conceptual principles of land reform. Thus, an alternative to the collective farm form of land management was introduced and it was recognized as equal to the state, collective and lease forms.

Under the existing peculiarities of that time, let us try to identify the main directions of the transformation process. The first of them was the de-nationalization and privatization of property, lands of collective and state farms. Having completed this work, the authorities, together with economic entities, undertook to subdividing lands and property of the former farms in favor of their available members at the time. The fourth direction of land relations transformation did not begin in the 1990s. The moratorium on selling land introduced in Ukraine was generally explained by politicians first of all by the desire to prevent the purchasing of land from its owners very cheaply. It was justified when the land was not the capital and had no real price. The moratorium was also an objectively forced step of the State in response to problems, which required solving: conducting administrative-territorial reform, determining the boundaries of cities and villages, fixing the boundaries of municipal and agricultural lands, cadaster registering and zoning of rural areas.

The creation of shadow schemes for buying and selling land was more the result of the inability of state bodies to prevent abuses in the sphere of land use, delays in land trade through auctions, and so on. Under the conditions of the moratorium's constant continuation, there was an artificial restraint of increasing land cost, more and more peasants wanted to sell their land under shadow schemes. In 2018, there were several schemes in Ukraine for the alienation of farm lands: by concluding a lease agreement with further redemption after cancelling the moratorium; by giving powers of attorney authorizing other persons to alienate the land; concluding preliminary agreements in accordance with Article 635 of the Civil Code of Ukraine on the transfer of the right to alienate land in the future. Besides, the scheme of transferring marketable agricultural lands to the category of lands for personal farming, and eventually their using for other target purposes, became widespread. Such a scheme of land alienation has become the most widespread in Kyiv region, where cottages construction is being actively conducted.

At the same time it should be noted that the transformation processes at that time were understood somewhat simplified by the developers of the agrarian reform, namely as a necessity to redistribute the lands of collective and state farms in such a way as to abandon public (collective farm-cooperative) ownership and pass on to the domination of private property of land. Collective and state farms, as manufacturers of marketable agricultural products, had to give way to new organizational and economic structures. The reformers did not pay attention to the fact that the State provided perpetual use of land to collective and state farms for the whole life use, and they had disposed of it for almost 60 years.

At the height of transformation processes the issue of recognizing the right to collective ownership of land turned out to be quite complex. For example O.Kubalskyi considers that such a form of ownership did not exist in Ukraine, because it was not recorded in the Constitution of Ukraine ${ }^{16}$. A. Miroshnychenko thinks that there is a contradictory situation and so far it is not possible to find the similar approach to its assessment ${ }^{17}$. We share the opinion of V.Humeniuk and V.Poliiuk, who believe that this form of ownership in Ukraine was not effective, to be more exact, it existed for a very limited period of time and was, in fact, a transitional stage from collective and cooperative to private land ownership, i.e. its transformation took place in the process of reforming the agrarian sector of the economy ${ }^{18}$. Despite the possibilities of coexisting different forms of land ownership declared by the reformers,

\footnotetext{
${ }_{16}$ Кубальський О. Реформа 1861 р. і соціально-культурні трансформації в українському селі: історія і сьогодення // Український селянин. - Вип.2. - Черкаси, 2001. - С.86.

17 Мірошниченко А.В. Земельне право України. - С.151-152.

18 Гуменюк В.І., Поліюк В.П. Земельна реформа: правові аспекти. - К., 2005. - 368 с.
} 
the subdivision of collective farm lands from 1992 was carried out rapidly ( 4000 collective farms conducted subdivision that year $)^{19}$. However, receiving land ownership certificates by peasants lasted for 10 years ${ }^{20}$. The human factor was mainly holding back the process of the long-term land subdivision. The peasants were not prepared for such drastic changes, which were offered to them "from above", and therefore they were not in a hurry to leave the collective farms. At the same time, the peasants did not oppose the authorities' all-round de-collectivization.

The founders of collective agricultural enterprises (CAEs) were 10-12 villagers (head of the collective farm, chief engineer, chief accountant, agronomist and other former leaders of the collective farm). They got the opportunity to add shares of other fellow villagers to their (much larger) land shares. Thus, the problem of their opposition to de-collectivization was removed, and there was a civilized transition from the collective farm to the farming type of management. At the same time, the rest of the peasants, members of the former collective farm, although they expanded their land plots a little, found themselves outside the process of CAEs formation. They undertook the arrangement of their personal farms. It so happened that CAEs faced various problems of material and technical provision on their farms (obsolete equipment, financial debts, etc.), most of which could not be overcome, and by the end of the 1990 s more than $90 \%$ of CAEs had become unprofitable ${ }^{21}$.

In the general course of agricultural lands' denationalization, certain peculiarities took place in the western regions of Ukraine. The local peasants still remembered the boundaries of the land plots, which had belonged to their parents, so they tried to get exactly those areas. However, in practice it was unreal. Although it should be mentioned, that in these regions the process of creating individual farms was faster and more intensive than in the center and east of Ukraine. In Ternopil region, 181000 of such farms were registered, in Volyn region - 141 000, in Chernivtsi region - 115 000, in Ivano-Frankivsk region -109 000, and in Zakarpattia region $-96000^{22}$. Without the necessary farm machinery, and often health to cultivate the land (3-6 ha), the peasants, having worked 2-3 years in their fields, began to rent out their land plots. At that time, the founders of CAEs were mainly leaseholders, and $85 \%$ of such agreements were concluded (10\% - with business structures $)^{23}$.

Transformations in the whole complex of property relations during the transition from the collective and state farm system to CAEs are not the subject of our study. We proceed only from the fact that without a sufficient amount of modern movable and immovable property, the transformation of land relations, increasing economic efficiency is impossible. The property of collective and state farms, and these were tens of millions of livestock and poultry, hundreds of thousands of tractors, cars, combines and other farm machinery, thousands of farms, in case of their preserving, had to become an important factor in demonstrating the benefits of conducted transformation. It turned out that no one was interested in preserving the property of collective farms. Peasants were given the right to share it, which resulted in the great destruction of the material and technical base of agriculture in Ukraine ${ }^{24}$. Scientists have still to study this process and its consequences for the agrarian sector.

With the adoption of the new Constitution of Ukraine in 1996, which fixed two forms of land ownership - public (state and communal property) and private ( the property of individuals and non-state legal entities), the first stage of land reform was completed. Its main result was land denationalization and its transfer to owners (shares). At that time, $9500 \mathrm{col}$ lective farms or $98 \%$ of their total number had already been reformed. On their basis, CAEs,

\footnotetext{
19 Кулъчицький С.В. Ринкові реформи в сільському господарстві. - С.16.

20 Гончарук Н.Б. Правові засади утвердження приватної власності в аграрному секторі економіки України. - С.340.

21 Коріненко П.С. Трансформація земельних відносин в українському селі. - С.372-373.

22 Хвесик М.A., Голян В.А., Крисак А.І. Інституційні трансформації та фінансово-економічне регулювання землекористування в Україні. C.115.

23 Соціально-економічні аспекти реформ в агропромисловому комплексі України (1991-1998 рр.). - С.144.

${ }_{24}$ Майовець Є.Й. Теорія аграрних відносин. - С.81-82.
} 
unions of peasants and cooperatives, farms, etc. were created. This was the transition period from public to private ownership of land, which developed according to the "revolutionary scenario", mainly by administrating. There was de-collectivization, farming, and individual farms' formation. It should be mentioned that even such significant events mentioned above could not overcome the crisis. On the contrary, the economic consequences of land relations' transformation at the first stage of land reform were unsatisfactory. Agricultural production decreased by 35\%. The new structures, first of all CAEs (there were 10500 of them in 1997), did not cope with the economic problems, but acted as a restraining factor preventing from increasing social unrest ${ }^{25}$. Peasants were divided into groups in disposing of their land shares: some began their own farming, others - rented out shares.

The beginning of the second stage of agrarian reform can conditionally be dated by 1997. With the completion of subdividing and certifying land shares, conditions were created for the further development of lease relations at a qualitatively new level. With issuing the Decree of the President of Ukraine "On Land Lease" (1997), land plots owned by citizens and legal entities, territorial communities of villages, and the state were included in the lease objects. These steps were aimed at facilitating the search for an effective master on land through leasing to which other groups of the population gained access. Regarding the social background of farmers, it should be mentioned that only $10 \%$ of them were former members of collective farms. This happened because the land transfer mechanism allowed all citizens of Ukraine to be engaged in farming, while certain sum of money was necessary to start one's own business.

The transformation of land relations, in particular, the conclusion of land lease agreements by farmers, created serious economic problems for peasants. Land lease agreements were short-term, which negatively affected the efficiency of such land utilization, as there was no stimulus to introduce optimal crop rotation, fertilizer application, etc. On the other hand, expanding the number of leaseholders really created the conditions for the emergence of new economic entities on the land. However, under the pressure of the left-wing political forces, in 1998, the Verkhovna Rada passed the Law of Ukraine "On Land Lease", which terminated the creation of new economic structures, which, in fact, was an attempt to revive collective farms.

Despite the activation of lease relations, as a whole, their level remained quite low in comparison with other Eastern European countries. This was primarily the result of the backwardness of agriculture, in particular low production volumes, because the determining criterion for land ownership is not the availability of land ownership, but the income, which can be obtained from it. Therefore, in the EU countries, the rent for the utilization of agricultural land makes $20-25 \%$ of the yield cost, or $2,5 \%$ of the land cost. In Ukraine, the rent made only $15-17 \%$ in comparison with the EU countries.

In our country, the relationship between leaseholders and landowners remained poorly regulated. The legislation envisaged that the lower limit of the rent had to be at least $3 \%$ of the standard monetary land evaluation, but this rate was not always and not everywhere observed. Thus, the rent to $14 \%$ of peasants made less than one percent of the monetary evaluation. On the whole, the undetermined rental potential and low rents forced a significant number of the rural population to sell their land shares at low prices. In addition, the difference between the real price of manufactured product and the price of rented out land made 50-100 times. As a result, the peasants did not actually benefit from land ownership. Moreover, contrary to the law, some individuals bought land in large amounts, often fraudulently. The peasants were also outraged by the fact that many farm heads rented out the land of CAE members without any permission to persons who were not agricultural producers.

Such ambiguous processes also took place because at that time the attitude of ordinary citizens to new patterns of rural management, and especially to private land ownership, was

${ }_{25}$ Статистичний щорічник України. - К, 1998. - С.127. 
still quite contradictory. According to a survey conducted in 1998 by scientists from the National Agrarian University, it was found that about $25 \%$ of respondents wanted to become farmers and about $13 \%$ - tenants. The attitude to the business patterns was as follows: a little more than a third of the heads of economic subdivisions considered it expedient to preserve collective farms; farmers were supported by about $13 \%$, joint-stock companies $8,9 \% .22 \%$ were ready for the immediate introduction of private ownership of land, and $39 \%$ believed that land had to be the national property ${ }^{26}$.

At the end of the 1990s, the crisis phenomena in the agrarian sector of Ukraine did not decrease, but on the contrary, they increased. And this happened despite the fact that a lot had already been done in the reforming. Land subdivision had been finished, the number of land users had increased by 12 times, new organizational and economic forms, CAEs, had been created, lease relations had become a reality. Nevertheless, as of 1999, 85\% of CAEs were unprofitable, agricultural production decreased by $51,3 \%$, more than 2 million land plots remained uncultivated, in particular, in Ternopil region almost $200000 \mathrm{ha}^{27}$. There were various reasons for these threatening processes for Ukraine's food security. At that time, the crisis in Ukraine was at the macroeconomic level. The state did not provide the necessary subsidies to farmers, capital investments in production facilities decreased by several times, and the tax burden was too heavy, so not all new owners were able to develop agricultural production.

Under such circumstances, in 1999 the Presidential Decree "On Urgent Measures to Accelerate the Reformation of the Agrarian Sector of the Economy” was issued, according to which the state pursued the course of liquidating CAEs by their transformation to privately owned production structures and the lands of CAEs had to become the private property of their members in half a year. We can state that CAEs fulfilled their historical mission of "shock absorber" during the transition period, but did not fulfill their function of demonstrating the advantages in the economic sphere. The positive moment connected with the liquidation of CAEs is that the foundations were laid for multi-structuralism in the countryside. Private land ownership provided the combination of individual, family and collective forms of labor organization, including joint stock companies, limited liability companies, joint share companies, farms, agro-firms, etc. Approximately 1500 of CAEs were transformed into cooperatives with a hundred or more founders. According to S.Kulchytskyi, they essentially remained collective farms or state farms ${ }^{28}$.

Again, as it was in the early 1990 s, the peasants were faced with the question of what to do and what form of management to switch to. For the vast majority of peasants, the only way out of the situation was to rent out their shares. The only difference was that at first they transferred their shares to CAEs, and then - to leaseholders. Today we are already on the threshold of the third and last transfer by the peasants of their shares - their selling, which will objectively lead to the establishment of mainly large-scale commodity production. As compared with collective and state farms, these will be mega-structures. In fact, such processes began in the mid-1990s, when new lease relations between share owners and new economic entities were established rather rapidly. Agro-firms began to acquire the characteristics of latifundia (large landed estates; formally the leaseholders of land), which had millions of peasants' shares at their disposal ${ }^{29}$.

After the liquidation of the CAEs, two types of producers began to be formed more distinctly: individual and corporate. As for individual farms, it should be noted that at that time there was already extensive network of them. They occupied an important place among other economic structures. At the same time, the formation of several types of farms was

\footnotetext{
26 Соціально-економічні аспекти реформ в агропромисловому комплексі України (1991-1998 рр.). - С.88-91.

27 Голос України. - 2003. - 7 жовтня. - С.3; Інституціональні трансформації та фінансово-економічне регулювання землекористування в Україні. - С.13.

28 Кульчицький С.В. Ринкові відносини в сільському господарстві. - С.18.

29 Третяк A.M. Історія земельних відносин і землеустрою в Україні. - С.185.
} 
completed: personal peasant farms (PPFs); personal subsidiary farms of peasants (PSF); subsidiary farms of enterprises, organizations and institutions; collective horticultural cooperatives. In 2008, the peasants' subsidiary farms had $42,5 \%$ of the land and they manufactured $54 \%$ of products ${ }^{30}$.

In the early 2000s, 13723 new agricultural enterprises were created on the basis of the former CAEs, including 1030 farms, 2840 private enterprises, 6402 partnerships, and 3312 agricultural cooperatives. And only a little more than 400000 peasants cultivated their land shares ${ }^{31}$. The above presented statistics shows that with the liquidation of the CAEs there were profound transformations in land relations and, first of all, changes in land ownership and its users. $98,8 \%$ of lands were disposed by non-state agricultural enterprises, $17,8 \%$ of lands were given to the citizens as private ownership and for using, and 2,0\% of lands were transferred to farms $s^{32}$. The facts of fictitious farming were not uncommon, when farms were registered on nominees of officials' relatives who received illegal income through the tillage of land by agricultural producers and free of charge use of peasants' property. The creation of a large number of farms in 1992-1995 was characterized by several factors: the relative easiness (though not always) of their registration, the chance to obtain land without payment, the plot exceeding the average land share for a particular locality, favorable tax climate, the opportunity to receive credit resources for a significant period and at a low interest rate. It is worth considering the desire of part of the population of Ukraine (and not only rural) to be an independent owner of land. At that time, economic conditions were more favorable for farming.

Personal peasant farms (PPFs) are the main segment of rural employment. They have become the place of occupation for at least $40 \%$ of those engaged in work in rural areas. Land plots of PPFs of up to 2 ha were given to the citizens of Ukraine from the state and communal property. Many peasants increased their holdings at the expense of pastures. By the mid-2000s, about 7 million peasants had worked on PPFs. The acreage of their lands had increased 6 times as compared with 1991 and had reached 6,3 million ha ${ }^{33}$.

At the same time, it should be mentioned that the processes taking place on and around PPFs are not simple. Firstly, a gradual reduction in their number is registered. Accordingly, the land area at their disposal has decreased. In 2000, they owned 6665400 ha, while in 2012 - 6501000 ha of land ${ }^{34}$. Another problem for the PPFs is utilization of land. It is abandoned, not cultivated because of old age, low incomes and high tillage costs. Many young peasants go to work in cities, other regions, and abroad. Personal plots of land are being turned into wasteland, and shares in the fields have long been rented out to large product manufacturers. There is reason to believe that after some time the leased shares will become their property. According to L.Antipova's calculations, the lease of shares has already covered more than $90 \%$ of lands, first of all, arable lands ${ }^{35}$.

Finally, the PPFs are a step back, which led to land spreading apart. Although it should be taken into account that the land plots of PPFs are a kind of insurance for the state in case of any problems in the food market, and therefore it is important to keep using the land received by the peasants during the collective farm lands' subdivision. Modern economists consider that the future of PPFs will be affected by such limiting factors as land resources, which will be difficult to increase with each passing year, as well as demographic, economic and social changes ${ }^{36}$.

\footnotetext{
30 Падалка С.С. Приватизація в Україні: перші підсумки та уроки (1991-2009). - С.296.

31 Хвесик M.A., Голян B.A., Крисак A.I. Інституціональні трансформації та фінансово-економічне регулювання землекористування в Україні. - С.14.

32 Третяк A.M. Історія земельних відносин і землеустрою в Україні. - С.210.

33 Малік М.Й., Заяць B.M. Теоретичні засади та напрями трансформації особистих селянських господарств. - С.89.

34 Там само. - C.92.

35 Антипова Л.І. Залучення зарубіжного досвіду в організації земельно-орендних відносин // Економіка АПК. - 2007. - №1. - С.147.

36 Березівський П., Войнича Л. Методика оцінки ресурсного потенціалу особистих селянських господарств з позиції системного підходу // Аграрна економіка. - 2013. - Т.6. - №3-4. - С.70-74.
} 
PPFs are important and often the main sources of income for rural families. At the same time, they continue to remain unviable forms of agriculture, as they are unable (financially) to acquire material and technical resources. This process is constrained by inefficient and imperfect selling and trading. New schemes of obtaining material and technical resources are slowly developing. The quality of products manufactured by PPFs also needs to be improved.

The transformation of land relations during the years of independence turned out to be such, at which every peasant was forced to look for his (her) niche in the manufacturing of farm products. We mean the emergence of personal subsidiary farms (PSFs) - land plots provided for the cultivation of farm products (including marketable) and procurement of feed for farmers' own livestock and poultry ${ }^{37}$. According to the decision of the village council, the peasants received 0,6 ha plots of land free of charge on property rights. However, it so happened that in reality the land plots of PSFs turned out to be larger than those of PPFs. The peasants increased the land plot area by adding part of the reserve fund lands, public pastures to their shares with the permission of the village council, as a result of which the land acreage of PSFs increased almost by $6^{38}$. If we try to predict the future of PSFs, we can affirm that the majority of them will not be able to compete with large agricultural producers. This will mean that the number of the middle class in the countryside will decrease.

Since 1985, collective horticulture, in fact, has become a nation-wide movement. Hundreds of thousands of city dwellers returned to land. In 1998, 2635000 citizens had 293700 ha of land. Land plots with an area of 0,04-0,06 ha were given free of charge by executive committees of district councils from former collective farm lands in coordination with village councils. They were received as single land areas by workers, employees at their places of employment, and then the plots were united into horticultural cooperatives. Over time, summer residents in the countryside were able to privatize their 0,06 ha. At present, the situation is that, according to some estimates, some of these lands are not used for their intended purpose. A new impetus to the process of increasing the number of land users is given by the decision of the Cabinet of Ministers of Ukraine to provide land to the ATO (anti-terror operation) participants. However, the search for vacant lands for the ATO participants turned out to be quite problematic for local authorities.

A separate niche, and in addition concerning the amount of leased land and the volume of agricultural production, is occupied by large producers - agro-firms and agro-holdings. They lease land from the former CAEs and individual farmers. As of 2011, there were approximately 50-60 agro-holdings in Ukraine, which used more than $24 \%$ of the land, "Ukrlandfarming" leased 522000 ha of land, "Ukrainian Agrarian Investments" 336000 ha, and "Myronivskyi Khliboprodukt" - 290000 ha (agro-holdings leased land for $4-5$ years $(48,9 \%)$ and for $1-3$ years $-10 \%)^{39}$.

As a whole, agro-holdings are increasing the areas of leased land, creating processing enterprises, building elevators, opening transport and trade organizations, and scientific institutions. The example is the "Nibulon" agro-holding (the Netherlands, Belgium, and Ukraine). Its shareholders invest their capital in the processing sector: vegetable oil, sugar, etc. Instead, they still pay too little attention to the social sphere in the countryside. There is a just concern in the society about their policy of excessive cultivating such crops as rape, sunflower and corn. Competitive advantage is achieved by them through the application of new technologies, logistics, and product quality control.

\footnotetext{
37 Земельний кодекс (Закон від 13 березня 1992 p., №2196-XII). Ст.56 [Електронний pecypc] https://zakon.rada.gov.ua/laws/show/2196-12\#Text

38 Падалка С.С. Приватизація в Україні: перші підсумки та уроки (1991-2009). - С.314.

39 Черевко Г. Агрохолдинги як оптимальні форми крупнотоварного господарювання в агробізнесі України. - С.39-40; Aндрійчук B. Агропромислові формування нового типу в контексті стратегії розвитку вітчизняного сільського господарства. - С.5-6.
} 
Agro-firms are slightly smaller concerning the area of leased land, although in general they use more than 6 million ha of land. At the same time, there is a tendency to increase their land areas. "Zoria Podillia" in Vinnytsia region, "Zoria" in Rivne region, "Havrylivski Kurchata" agro-firms and others are rather powerful. According to foreign experts, they are bigger than similar foreign structures.

Thus, the main directions of land relations' transformation during the years of Ukraine's independence were the denationalization (privatization) of collective and state farms' lands, and the formation of new economic entities on the land; giving up the planning in the agrarian sector and the transition to market conditions. Land subdivision, the spreading of lease relations, the transformation of the CAEs into private economic structures were the main organizational and legal actions, which gave a real shape to the transformation of land relations. According to their significance and range, the whole period can be conventionally divided into three stages. The first one lasted from 1991 to 1996, i.e. till the adoption of the Constitution of Ukraine. At that time, 14,9 thousand new agricultural formations were created and 5,6 million lease agreements of land shares with an area of 32 million ha were concluded $^{40}$.

The transformation of land relations at the first stage considering the historical process took place as if in the opposite direction - from the socialist (collective) land use - to the capitalist one (private, mostly individual). It was impossible to overcome this difficult period safely. As a result, there was land spreading apart, the transition from large-scale agricultural commodity production to small-scale production. The top of justice in land relations was that at the first stage the state gave the land to the peasants free of charge. However, the unpredictable event happened: the majority of peasants, having received State Land Shares Use Entitlements, immediately began to rent them out to CAEs, agro-firms, and agro-holdings. In fact, in the modern transformation of land relations in Ukraine, the European experience has been confirmed, which proves the necessity and regularity of the existence of various forms of land management. This process requires special research by historians, economists, and sociologists.

At the second stage of the agrarian reform, peasants rented out their shares to individual farmers and agro-firms. In fact, there was a process of peasants' abandoning the land, and getting accustomed to living on rent. The slogan "Land to those who cultivate it" acquired a completely different social meaning. A complicating circumstance was that the legal support of these large-scale processes was not always at the proper level. If in 1991, 0\% of land was privately owned, in $2007-50,9 \%{ }^{41}$.

The third, final, stage of land relations' transformation envisages the provision of such a disposal of land share as its selling. This process has already begun. The transfer of land rights will no longer take place on the basis of a lease agreement, but on a monetary basis.

Summing up, we can affirm that the transformations of land relations in Ukraine are permanent. They take place at the request of the society, but they are carried out by the present power authorities that establish the corresponding legal relations, determines goals and tasks. The transformations of land relations have turned out to be so large-scale and multi-vector that they in fact, have become, the "agrarian revolution". A new land order has begun to take shape: the state monopoly on land was abolished, transition to various forms of land ownership was made, the land was redistributed free of charge for the benefit of citizens, paid (for leasing) land use was introduced, and agricultural land circulation began. Decollectivization, denationalization and privatization of lands have been chosen as the means of implementing such projects. The initiative for de-collectivization was put forward by the

\footnotetext{
40 Гладій M. Реформи на селі були неминучими // Урядовий кур'єр. - 2001. - 6 лютого. - С.4-5.

41 Хвесик M.A., Голян B.A., Крисак А.І. Інституціональні трансформації та фінансово-економічне регулювання землекористування в Україні. - С.127, 131.
} 
Government structures and political parties. Accordingly, the organizational and economic structures in the countryside were rebuilt. The authorities' mistake was that even those collective and state farms, which were highly profitable (the so-called "millionaires") were broken up.

De-collectivization led to radical changes in the social structure of the village: the collective farm peasantry disappeared and farmers, hired workers, and the unemployed appeared. The structuring of organizational and economic forms (PPFs, PSFs, agro-firms, and agro-holdings) shows that in Ukraine the radical redistribution of land on a lease basis has already been completed. During the next and last stage - the circulation of agricultural lands will make significant changes in the ratio of the number of landowners and the amount of land, which will be owned by them. We note that the transformation of land relations is multi-vector, but it has not yet solved many problems. At present and in the near future, it is possible to predict further transformation of land relations. These include a decrease in the amount of lands per capita; withdrawal of lands from agricultural circulation for construction, the development of infrastructure, etc. Considering these possible realities, the problem of preserving medium farming will become more acute, which is connected with the increasing asymmetry in the ratio of land ownership by PPFs, PSFs, agro-firms, and agro-holdings.

\section{REFERENCES}

1. Andriichuk, V.H. (2013). Ahropromyslovi formuvannia novoho typu u konteksti stratehii rozvytku vitchyznianoho silskoho hospodarstva. Ekonomika APK, 1, 3-15. Kyiv. [in Ukrainian].

2. Berenshtein, L. (Ed.). (1998). Sotsialno-ekonomichni aspekty reform v abropromyslovomu kompleksi Ukrainy (1991-1998 rr.). Kyiv. [in Ukrainian].

3. Berezivskyi, P., Voinycha, L. (2013). Metodyka otsinky resursnoho potentsialu osobystykh selianskykh hospodarstv z pozytsii systemnoho pidkhodu. Abrarna ekonomika, 6, 3-4, 70-74. Lviv. [in Ukrainian].

4. Cherevko, H. (2012). Ahrokholdynhy yak optymalni formy krupnotovarnoho hospodariuvannia v ahrobiznesi Ukrainy. Abrarna ekonomika, 5, 1-2, 36-42. Lviv. [in Ukrainian].

5. Haidutskyi, P.A. (2015). Ahrarna reforma L.D.Kuchmy v Ukraini: istoryko-ekonomichni aspekty. Ekonomika APK, 1, 5-13. Kyiv. [in Ukrainian].

6. Honcharuk, N.B. (2001). Pravovi zasady utverdzhennia pryvatnoi vlasnosti v ahrarnomu sektori ekonomiky Ukrainy. Ukrainskyi selianyn, 3, 336-342. [in Ukrainian]

7. Horbulin, V.P. (Ed.). (2010). Zemelni vidnosyny v Ukraini: Zbirnyk informatsiino-analitychnykh materialiv (1991-2010 rr.). Kyiv. [in Ukrainian].

8. Humeniuk, V.I., Poliiuk, V.P. (2005). Zemelna reforma: pravovi aspekty. Kyiv. [in Ukrainian].

9. Khvesyk, M.A., Holian, V.A., Krysak, A.I. (2008). Instytutsionalni transformatsii ta finansovo-ekonomichne rebuliuvannia zemlekorystuvannia v Ukraini. Kyiv. [in Ukrainian].

10. Korinenko, P.S. (2018). Pravovi zasady abrarnoi polityky v Ukraini (dr. pol. XX - pochatku XXI st.): Istorychnyi aspekt. Ternopil. [in Ukrainian].

11. Korinenko, P.S. (2019). Transformatsii zemelnykh vidnosyn v ukrainskomu seli (XX - pochatok XXI st.): Porivnialnyi analiz. Ternopil. [in Ukrainian].

12. Kubalskyi, O. (2001). Reforma 1861 roku i sotsialno-kulturni transformatsii v ukrainskomu seli: istoriia i sohodennia. Ukrainskyi selianyn, 2, 83-87. Cherkasy. [in Ukrainian].

13. Kulchytskyi, S.V. (2002). Rynkovi vidnosyny v silskomu hospodarstvi. Ukrainskyi selianyn, 4, 14-19. Cherkasy. [in Ukrainian]

14. Lopatynskyi, Yu.M. (2006). Transformatsiia abrarnobo sektora: instytutsionalni zasady. Chernivtsi. [in Ukrainian].

15. Maiovets, Ye. (2005). Teoriia a hrarnykb vidnosyn. Kyiv. [in Ukrainian].

16. Malik, M.J., Zaiats, V.M. (2013). Teoretychni zasady ta napriamy transformatsii osobystykh selianskykh hospodarstv. Ekonomika $A P K, 5,83-95$. [in Ukrainian].

17. Miroshnychenko, A.M. (2009). Zemelne pravo Ukrainy. Kyiv. [in Ukrainian].

18. Miroshnychenko, A.M., Marusenko, R.I. (2013). Naukovo-praktychnyi komentar Zemelnoho kodeksu Ukrainy. Kyiv. [in Ukrainian].

19. Padalka, S.S. (2010). Pryvatyzatsiia v Ukraini: pershi pidsumky ta uroky (1991-2009). Kyiv. [in Ukrainian].

20. Sharyi, H.I. (2014). Suchasni zemelni vidnosyny na seli. Ekonomika APK, 4, 12-17. [in Ukrainian].

21. Shulha, M.V., Zhushman, V.P., Kulynych, P.F., Urkevych, V.Yu. (2004). Fermerske hospodarstvo: pravovi zasady stvorennia, funktsionuvannia ta prypynennia. Kharkiv. [in Ukrainian].

22. Tretiak, A.M. (2002). Istoriia zemelnykh vidnosyn i zemleustroiu v Ukraini. Kyiv. [in Ukrainian].

23. Tretiak, A.M. (1999). Zemelnyi kodeks XXI stolittia. Kyiv. [in Ukrainian]. 


\author{
Павло КОРІНЕНКО \\ доктор історичних наук, професор кафедри історії України, археології та спеціальних галузей історичних наук, \\ Тернопільський національний педагогічний університет ім. В.Гнатюка \\ (Тернопіль, Україна), korinenko@tnpu.edu.ua \\ ORCID: https://orcid.org/0000-0002-4068-1491
}

\title{
Сергій ПАДАЛКА
}

доктор історичних наук, професор, провідний науковий співробітник, відділ новітньої історії та політики, Інститут історії України НАН України

(Київ, Україна), seriogap@ukr.net

ORCID: https://orcid.org/0000-0001-8478-5332

\section{Наталія ВАРОДІ}

кандидатка історичних наук, доцентка кафедри історії та суспільних дисциплін,

Закарпатський угорський інститут ім. Ференца Ракоці II

(Берегове, Україна), varadinatalia29@gmail.com

ORCID: https://orcid.org/0000-0003-4175-4928

\section{Земельні відносини в розрізі соціально- економічних трансформацій українського села за роки незалежності: наукові оцінки та прогнози}

\begin{abstract}
Анотація. Мета дослідження полягає в аналізі трансформацій земельних відносин в українському селі з проголошенням незалежності. Зміни в користуванні, розпорядженні землею, а також появи нових організаційно-господарських форм господарювання в агросекторі були радикальними, а отже й неоднозначними за своїм характером. У дослідженні використано загальнонаукові методи, зокрема порівняльно-історичний і системно-структурний, які допомогли впорядкувати значне число джерельного матеріалу, відтворити та порівняти спрямованість трансформації земельних відносин на різних етапах цього процесу. При визначенні структури дослідження використано проблемно-хронологічний підхід. Наукова новизна полягає у вивченні проблеми, яка в українській історіографії не студіювалася в такій постановці та хронологічних рамках. Аграрна реформа в Україні, насамперед реформування земельних відносин, послідовно розглядаються від поширення оренди, розпаювання серед селян - до відкриття ринку земель сільськогосподарського призначення. Проаналізовано об'єктивні й суб'єктивні чинники, які ускладнювали названі процеси та, зокрема, відставання у формуванні комплексу правових засад. Висновки. Висвітлено вплив трансформацій земельних відносин на здобутки і втрати в аграрному секторі України. Автори констатують, що поспішне запровадження нових форм господарювання на землі без належного теоретичного обгрунтування, фінансового забезпечення робило процес реформування впродовж 30 років слабко прогнозованим. Селяни тривалий час не були впевнені в незворотності трансформації земельних відносин, що підтверджується доволі сповільненими темпами отримання ними державних актів права власності на земельні паї. Відзначається, що органи влади усвідомлювали складність проблеми, тому було запропоновано повільний перехід від колгоспно-радгоспної системи - через КСП - до ОСП та ОПГ. Агрофірми й агрохолдинги виявилися кульмінацією нової структури господарювання на землі. Проаналізовано зміни у структурі агрокультур і тваринництва, які стали наслідком трансформації земельних відносин. Простежено зміни у житті селян, насамперед налаштованість більшості з них на дрібнотоварне виробництво. Зроблено поетапний огляд стану матеріально-технічної бази аграрного сектора.
\end{abstract}

Ключові слова: трансформація земельних відносин, земельний пай, оренда землі, фермерство, ринок земель сільськогосподарського призначення. 